\title{
GENERATION OF LAND QUALITY INDEX FOR AGRICULTURAL USAGE AT GÜVENÇ BASIN, TURKEY
}

\author{
DEDEOĞLU, M. \\ Selçuk University, Agriculture Faculty, Department of Soil Science and Plant Nutrition \\ 42100 Konya, Turkey \\ e-mail: mertdedeoglu@gmail.com; phone: +90-530-416-0006 \\ (Received 26 $6^{\text {th }}$ Oct 2019; accepted $30^{\text {th }}$ Jan 2020)
}

\begin{abstract}
The aim of this study is to develop the land quality index (LQI) based on expert opinion and multi-criteria decision support approaches for agricultural lands. The study was conducted on 8 soil series and 20 land units belonging to the lands of Ankara-Güvenç Basin, Turkey which covers about $17.5 \mathrm{~km}^{2}$, representing the ecological conditions of a semi-arid climate. In this research, 9 main indicators were chosen including depth, slope, stoniness, bulk density (BD), texture, electrical conductivity (EC), $\mathrm{pH}$, organic matter (OM) and $\mathrm{CaCO}_{3}$. Analytical Hierarchical Process (AHP) method was used a pairwise comparison of indicators. As a result of the LQI assessment, while $17.14 \%$ of the lands were classified as "High" and $37.41 \%$ Moderate, the agricultural quality class of $41.55 \%$ of the studies land was determined as "Low" and "Very Low" and mapped in GIS. In this study, it was determined that the final index value of the land was affected by depth $(24.2 \%)$, slope $(21.1 \%)$ and bulk density $(16.6 \%)$ indicators with high weight coefficients. In addition, the values of the LQI were compared with Normalized Difference Vegetation Index (NDVI) values for testing and it has been determined that land quality assessment for agricultural usage has been performed with high accuracy for NDVI $\left(r^{2}=0.74 \%\right)$. Finally, the results of the study showed that the LQI was achieved for micro basin scale under semi-arid climate conditions.
\end{abstract}

Keywords: analytic hierarchy process, GIS, land indicators, NDVI, semi-arid climate

\section{Introduction}

Sustainable agricultural production is most important target of agricultural policies of developed or developing countries (Kumar and Jhariya, 2015). In the line with this target, these policies aim to balance the soil with the requests of the product to be grown and to ensure the long-term efficiency by optimizing the resource utilization (Joshua et al., 2013). To achieve these aim and objectives, the determination of land quality in the planning of sustainable agricultural practices has been one of the important ecological approaches in the World (Xue et al., 2019). Land quality is defined as the capacity of the functions resulting from the nature of the soil within a certain ecosystem and depending on its use under a certain management (Karlen et al., 2013). The determination of this capacity requires a multi-decision approach that requires the standardization and weighting of the effects of many factors that affect each other, such as physical, chemical, morphological, topographic and climatic soil characteristics, which are interrelated and differentiated (Mokarram and Mirsoleimani, 2018). Many methods have been developed for land quality assessment, from qualitative or semiquantitative visual approaches (Shepherd, 2009) to quantitative methods based on laboratory analysis and calculating land quality index using mathematic and statistical methods (Karlen et al., 1998; Imaz et al., 2010; Askari and Holden, 2014). The indexing methods are most commonly used (Rahmanipour et al., 2014), usually integrating several indicators associated with soil functions appropriate to the intended use into a quantitative factor that can be used for multi-criteria decision making (Karlen et al., 1998). Thus, AHP (Saaty, 1980), which is the Multiple Criteria Decision Analysis, is preferred in the evaluation of multiple - 
heterogeneous factors (Ceballos and Lopez, 2003; Malczewski, 2006; Dengiz and Sarıoglu, 2013; Akıncı et al., 2013; Askari and Holden, 2014; Xue et al., 2019; Özkan et al., 2019). AHP is a decision-supported method that divides complex multiple-factor problems into a hierarchical structure (Yang et al., 2008). At the same time, integration of analytical models with geographic information system (GIS) is reliably used by researchers in the production and interpretation of LQI maps (Malczewski, 2006; Yalew et al., 2016). The LQI is commonly developed using a four-step process: indicator selection, indicator standardization and scoring to sub criteria, weighting of indicators according to importance level, and calculation of scores into a model (Andrews et al., 2004; Askari and Holden, 2014; Xue et al., 2019). But there is no comprehensive LQI that can be used as a universal method across regions and scales (Zhang et al., 2004), and many LQI have been developed for specific purposes and index are usually valid under particular environmental conditions (Imaz et al., 2010; Askari and Holden, 2014). Thus, it can be unexpected that there is index that can determine the land and soil characteristics for all geographies, type of usage and plant species for land quality (Bydekerke et al., 1998; Store and Kangas, 2001). At the same time, it is not practically possible to develop a model that can represent all ecological variables and sociocultural habits, but in theory it is not economic in terms of time, labor and cost (Doran and Parkin, 1996). Therefore, similar studies should be conducted to determine the quality of agricultural lands under different management systems in Turkey (Dengiz et al., 2014). In this study, it was aimed to develop an agricultural land quality index which is genuine to the semi-arid terrestrial climate ecology of Central Anatolia and applicable in the similar geographies by using the expert opinion and AHP approaches. In addition to that, the land of the region was mapped in GIS environment by scoring quality of the basin lands. At the same time, the success of the developed index was tested by comparing the plant density values derived from Sentinel 2A satellite image. Finally, the quality map was produced in GIS environment to decision makers and agricultural policy producers to be a base for land management planning.

\section{Materials and Methods}

\section{Field description and study}

Güvenç Basin is located between $40^{\circ} 08^{\prime} 39^{\prime \prime}-40^{\circ} 06^{\prime} 13^{\prime \prime}$ North latitudes, $32^{\circ} 44^{\prime} 39^{\prime \prime}$ - $32^{\circ} 47^{\prime} 59^{\prime \prime}$ East longitudes in the Ankara province of Central Anatolian, Turkey (Fig. 1). The total area of the basin is $17.5 \mathrm{~km}^{2}$ and its altitude above sea level between $1040 \mathrm{~m}$ and $1440 \mathrm{~m}$. The distribution of land use types for the basin consist $45 \%$ of wheat, $35 \%$ of pasture, $11.2 \%$ of heath and garden, $8.2 \%$ of no tillage and rocky, $0.6 \%$ of pond (Turan and Dengiz, 2015).

In the study, phase separations (depth, texture, slope, stoniness) and spatial distributions of the soil series mentioned in the detailed survey report and map of the basin were used (Dengiz and Baskan, 2005). Thus, land quality assessments were made at the level of mapping unit. The soils of study area were classified into 8 different series, Typic Xerofluvent, Mollic Xerofluvent and Aquic Xerofluvent in 20 mapping units (land units) and Lithic Xerorhent in subgroups according to soil taxonomy (Table 1) (Soil Survey Staff, 1999). In order to determine soil properties affecting land quality, eight disturbed and undisturbed soil samples which are representing the predefined soil series were taken from topsoil between 0-30 cm depth in year of 2018 according to Soil Science Division Staff (2017). Basin soils reflect the typical soil characteristics in different slope 
groups formed from alluvial deposits of physiographic units and high calcareous, lowmoderate organic matter content, high $\mathrm{pH}$, stoniness and different depth classes developed under semi-arid climate conditions of Central Anatolia region. This situation indicates the presence of land in the basin which will represent different quality classes.

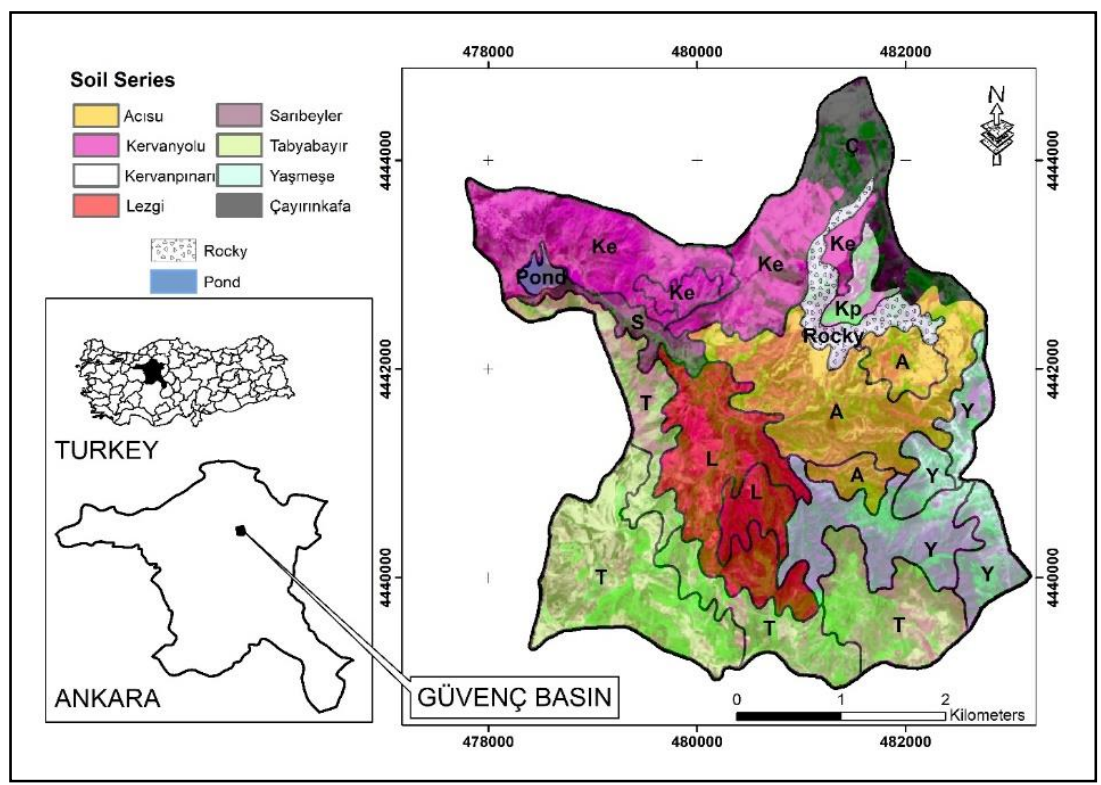

Figure 1. Soil series and location map of the study area

Table 1. Distribution of soil series in the basin according to Soil Taxonomy

\begin{tabular}{c|c|c|c|c}
\hline & Soil Series & Subgroups & Area (ha) & Proportion (\%) \\
\cline { 2 - 5 } & Acısu & Lithic Haploxerept & 285.16 & 16.18 \\
& Kervanyolu & Typic Xerorthent & 312.23 & 5.58 \\
& Kervanpınarı & Chromic Haploxerert & 29.43 & 17.71 \\
& Lezgi & Typic Haploxerept & 218.02 & 1.67 \\
BÜVENÇ & Sarıbeyler & Typic Xerofluvent & 37.36 & 12.37 \\
& Tabyabayır & Lithic Xerorthent & 479.97 & 0.67 \\
& Yaşmeşe & Typic Xerorthent & 233.73 & 3.23 \\
& Çayırınkafa & Vertic Haploxerept & 98.33 & 2.12 \\
& Rocky & - & 56.96 & 27.23 \\
& Pond & - & 11.74 & 13.24 \\
& Total & - & 1762.92 & 100 \\
\hline
\end{tabular}

\section{Climate characteristics}

Based on the climate values of the region for many years; it represents semi-arid climate characteristics of hot and dry summers and cold and rainy winters. The average annual rainfall and average temperature in the region for the last 20 years is $478.1 \mathrm{~mm}$ and $11.4^{\circ} \mathrm{C}$, respectively. The hottest month is July with $24.0^{\circ} \mathrm{C}$ and the coldest month is January with an average of $-3^{\circ} \mathrm{C}$ (Anonymous, 2017). According to soil climate regime of Newhall simulation model (Van Wambeke et al., 2000), the study area has Mesic soil temperature regime and Xeric (Dry Xeric in subgroup) moisture regime. Particularly, potential evapotranspiration is higher than precipitation between April and October. Soil needs irrigation particularly between May and July. 


\section{Indicator selection, sub-group scoring and weighting}

Nine parameters affecting crop development in agricultural land quality index; depth, slope, stoniness, $\mathrm{BD}$, texture, $\mathrm{EC}, \mathrm{pH}, \mathrm{OM}$ and $\mathrm{CaCO}_{3}$ were selected as the evaluation parameters using many literature (Huddleston et al., 1987; McVay et al., 1989; Soil Survey Staff, 1999; Arshad and Martin, 2002; Hazelton and Murphy, 2007; De La Rosa and Van Diepen, 2009; Iojă et al., 2014; Mustafa et al., 2017; Aldababseh et al., 2018). In this study, land indicators were produced as digital layers in GIS environment from the study report and map of the regional soils. The values of other indicators were obtained from the results of laboratory analysis. The laboratory analyses conducted in the research are presented in Table 2 and the descriptive statistics of the results are given in Table 3.

Table 2. Physicochemical analysis and methods performed in the study

\begin{tabular}{c|c|c|c}
\hline Indicators & Units & Procedure & References \\
\hline $\mathrm{BD}$ & $\mathrm{g} \mathrm{cm}^{-3}$ & Undisturbed soil samples & Blake and Hartge, 1986 \\
Depth & $\mathrm{cm}$ & Soil survey & Soil Science Division Staff, 2017 \\
Slope & $\%$ & Soil survey & Bouyoucos, 1951 \\
Texture & $\%$ & Hydrometer method & Nelson and Sommers, 1982 \\
$\mathrm{OM}$ & $\%$ & By Potassium dichromate $\left(\mathrm{K}_{2} \mathrm{Cr}_{2} \mathrm{O}_{7}\right)$ & \\
$\mathrm{pH}$ & $1: 2.5$ & Oxidation method (Walkley-Black) & Soil Survey Staff, 2011 \\
$\mathrm{EC}$ & $\mathrm{dS} \mathrm{m}$ & Soil-water suspension (w:v) & \\
$\mathrm{CaCO}_{3}$ & $\%$ & Scheibler calcimeter & \\
\hline
\end{tabular}

Table 3. Descriptive statistics of physical and chemical properties of soil series

\begin{tabular}{|c|c|c|c|c|c|c|c|}
\hline Indicators & Min. & Max. & Mean & StDev. & SE Mean & Variance & CoefVar \\
\hline $\mathrm{BD}, \mathrm{gr} \mathrm{cm}^{-3}$ & 1.21 & 1.42 & 1.32 & 0.07 & 0.02 & 0.01 & 5.52 \\
\hline Sand, \% & 25.80 & 52.44 & 36.60 & 11.44 & 3.62 & 130.78 & 30.33 \\
\hline Silt, \% & 16.60 & 25.20 & 22.40 & 4.61 & 1.46 & 21.24 & 21.14 \\
\hline Clay, \% & 28.84 & 64.66 & 40.64 & 10.06 & 3.18 & 101.18 & 24.81 \\
\hline OM, \% & 0.82 & 3.64 & 2.11 & 0.82 & 0.26 & 0.68 & 38.10 \\
\hline $\mathrm{pH}, 1: 2.5$ & 7.00 & 7.85 & 7.60 & 0.21 & 0.07 & 0.04 & 2.74 \\
\hline $\mathrm{EC}, \mathrm{dS} \mathrm{m}^{-1}$ & 1.12 & 1.44 & 1.32 & 0.18 & 0.06 & 0.03 & 13.65 \\
\hline $\mathrm{CaCO}_{3}, \%$ & 5.20 & 32.29 & 14.12 & 8.00 & 2.53 & 63.95 & 57.21 \\
\hline
\end{tabular}

The selection of indicators to determine the quality of the land is very important (Zhan et al., 2016). There are many characteristics that affect the quality of lands under different agricultural uses in varying amounts and it is not possible to use all of them (Karlen et al., 2013). In this regard, Doran and Parkin (1996), have suggested the use of as few parameters as possible in modeling approaches. Thus, it is known that there is a high correlation between some physical, chemical and biological properties, it is not practically possible to use all of them as indicators at the same time and it is stated that it is contrary to the basic principles of land evaluation measurement paradigm (Andrews et al., 2004). In another aspect, when numerous soil analysis is performed for model production, the application of the developed index becomes cumbersome (Askari and Holden, 2014). For this reason, the indicators used in the study were chosen according to an expert opinion and literature knowledge by taking into consideration the quality representation from one or more soil properties and their effectiveness is presented in Table 4, and sub-factor scoring of parameters is presented in Table 5. In addition, in the selection of land indicators, the phases specified in the detailed soil map and which are defined as limiting factor to plant growth were used. 
Table 4. Selected parameters for land quality index and their effectiveness

\begin{tabular}{|c|c|c|}
\hline Indicators & Effectiveness & Source \\
\hline Depth & Root development, water storage capacity & Sarkar et al., 2014 \\
\hline Slope & & \\
\hline Stoniness & Crop emergence & Miller and Guthrie, 1984; Sauer et al., 2010 \\
\hline Texture & $\begin{array}{c}\text { Infiltration rate, structure type, plant - water } \\
\text { relationship }\end{array}$ & Ahmed et \\
\hline Bulk density & Soil compaction, aeration, infiltration & Şeker and Iş1ldar, 2000; Pagliai et al., 2004 \\
\hline $\mathrm{EC}$ & & Mir \\
\hline $\mathrm{pH}$ & Nutrient availability, microbial activities & Baridón and Casas, 2014 \\
\hline Organic Matter & Soil quality, biological activities & $\begin{array}{l}\text { Riley et al., 2008; Guo et al., 2015; Kurzatkowski } \\
\text { et al.. } 2004\end{array}$ \\
\hline $\mathrm{CaCO}_{3}$ & Fixation of plant nutrients, aggregation & Erdal et al., 2000; Turgut et al., 2008 \\
\hline
\end{tabular}

Table 5. The sub-score values of the parameters to be used in the land quality index determined using expert opinion and literature knowledge

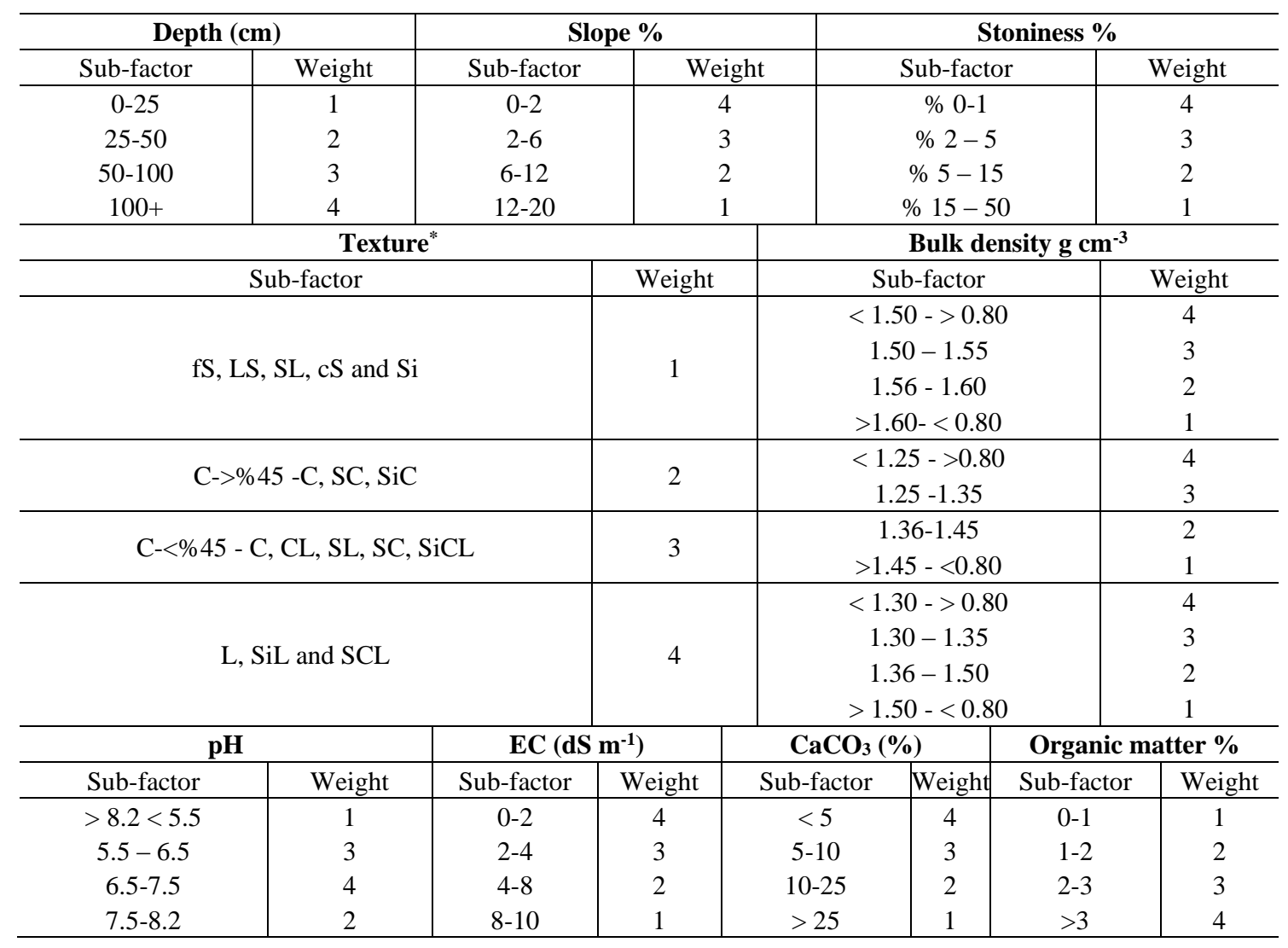

${ }^{*}$ fS: Fine sand, LS: Loamy sand, SL: Sandy loam, S: Sand, C: Clay, Si: Silt, SiC: Silty clay, cS: Coarse sand, SC: Sandy clay, CL:Clay loam, SiCL: Silty clay loam, L: Loam, SiL: Silt loam, SCL: Sandy clay loam

In the study, score values between 1 and 4 were assigned for the parameters of each indicator. The criterion classes are given as 4 in case agricultural farming is allowed and take value of 1 if agricultural farming is not allowed. These two values were evaluated according to the limiting factor and degree. Analytical Hierarchical Process (AHP), which is a multi-criteria decision-making algorithm, was used in pairwise comparison of the indicators of the study (Saaty, 2008). 


\section{Calculation to land quality index values of mapping units}

In order to determine the land quality scores of the study area, a parametric approach healed Linear Combination Technique (LCT) was applied to 20 different mapping units prepared by ArcGIS 9.3 (ESRI, 2010), a geographic information system program. LCT is a practical and reliable mathematical equation used in several similar studies in the evaluation of sub-factor scores and weight ratios of the parameters together (Eastman and Jiang, 1996; Dengiz and Sarığlu, 2013; Romano et al., 2015). The model for the LCT approach is presented in the following Equation 1.

$$
L Q I=\sum_{i=1}^{n}(W i . X i)
$$

Here LQI, Land quality index; Wi, i weight value of parameters; Xi, sub-criteria score belonging to i parameters; $n$, the total number of parameters discussed. Land quality index class ranges calculated according to Jenks (1967), were determined using the basis of ArcGIS 9.3 software (Table 6). The index values calculated for all mapping units were categorized according to the ranges of natural diffraction from the histogram graph (Zhang et al., 2015). In this way, an index was developed according to the degree of effect of the region-specific parameters on the final score value.

Table 6. Agricultural land quality classes

\begin{tabular}{c|c|c}
\hline Land Quality & Classes & Index Values \\
\hline High & I & $>2.850$ \\
Moderate & II & $2.554-2.849$ \\
Low & III & $2.061-2.553$ \\
Very Low & IV & $<2.061$ \\
\hline
\end{tabular}

Land quality classes were categorized as a "High: I' where there are no limiting factors for agricultural plant cultivation and development, "Moderate: II" where there are some slightly restrictive factors, "Low: III' where there are factors affecting cultivation at a severe level and "Very Low: IV' under conditions unfavorable for plant cultivation.

\section{Determination of biomass density}

Today remote sensing imaging is considered one of the main sources of information about the land vegetation (Campbell and Wynne, 2011; Singh et al., 2018). Vegetation index represent the most common remote sensing technique used for this purpose (Al-Doski et al., 2013; An, 2018), while NDVI is the most commonly used vegetation index (Tucker, 1979; DeFries et al., 1995; Garrigues et al., 2007; Tyagi and Bhosle, 2010; Olimb et al., 2018). For this purpose, Song et al. (2016), have stated that prediction coefficient with $\mathrm{R}^{2}$ of 0.87 was found between NDVI values obtained from Landsat 8 OLI satellite images for winter wheat at different growth periods and the yield values in a farm-based study. NDVI is sensitive to active photosynthetic compounds and is, therefore, a popular method used to measure the biomass of vegetation or "greenness" in a defined area (Mezera et al., 2017). Thus, the fit between biomass of winter wheat from the field and the NDVI values obtained for the same locations were well and significantly $(\mathrm{P}<0.05)$ correlated in the two regions, with coefficients of determination of 0.82 and 
0.92 (Li et al., 2019). In this study, a multitemporal Sentinel-2A images in the year 2018, May were used to calculate NDVI values which were utilized for validation LQI classes with biomass density. NDVI values were calculated according to the Equations 2.

$$
N D V I=(N I R-R E D) /(N I R+R E D)
$$

where,

NDVI= Normalized Difference Vegetation Index

NIR $=$ Near infrared band

$\mathrm{RED}=$ Visible red band.

Sentinel-2A has (1) a temporal resolution lower than a week, (2) a spatial resolution of up to $10 \mathrm{~m}$, and (3) narrow bands in the red and red-edge region, which makes it a highly reliable sensor for agricultural monitoring (Pasqualotto et al., 2019). The image was downloaded free of charge from the ESA server (https://scihub.copernicus.eu/) that provides Level-2A images that are geometrically and atmospherically corrected with topof-canopy (TOC) reflectance as cloud-free (Pandžić et al., 2016). In addition, it was used Erdas Imagine 9 (ERDAS, 2009) to perform NDVI analysis, and ArcGis 9.3 (ESRI, 2010) software was used to store data and generate thematic maps.

\section{Spatial statistical analysis and map production in GIS}

The Spatial Analysis tool of the software ArcGIS version 9.3 (ESRI, 2010) was used to spatially compare the LQI classes and NDVI values of the land units. The LQI and mean NDVI values of the land units were extracted using the Zonal Statistics tool and imported into MS Excel. Thereafter, all the data were statistically compared and regression equations, graphs, and accuracy coefficients $\left(\mathrm{r}^{2}\right)$ were produced.

\section{Results and Discussions}

In the study, the weight values of 20 mapping units based on pairwise comparisons for selected indicators for the determination of agricultural land quality were presented in Table 7.

Consistency Ratio; $\mathrm{CR}=0.09(<0.10)$ was determined by pairwise comparisons and the method was found to be valid (Saaty, 2008). In the pairwise comparison of obtained indicators evaluated by AHP; (1) land conditions for plant cultivation, (2) the importance of indicators and parameters relative to each other, (3) the elimination of the restrictive effects of the parameters and (4) by considering the degree of change of the parameters in the regional soils, weight scores were determined. Thus, in the studies carried out at the regional scale, the weight value of the region-specific characteristics (such as $\mathrm{pH}$ and $\mathrm{CaCO}_{3}$ ) is lower compared to other parameters, but high level scoring of non-economic (e.g. slope degree, effective soil depth) and continuous risk (stoniness) properties in the land improvement or modification is recommended (Patrono, 1998; Dengiz and Sarığlu, 2013; Ahmed et al., 2016). However, it is known that their presence in the environment is not necessary for crop production, but if it is found to influence soil quality (e.g. organic matter), it should also have a moderate weight ratio (Riley et al., 2008). Due to all these evaluations, as a result of the pairwise comparisons by taking into account the ecology of the region, the effect levels of the indicators considered in the agricultural land quality measurement of the basin soils were evaluated in 3 groups as high, moderate and low. The results of AHP applications indicated that depth (24.2\%), slope (21.1\%) and texture 
$(16.6 \%)$ indicators had a high-level weight coefficient. Although plants can grow in soils at different depths under favorable climatic conditions, usually optimum root development occurs in soils with high soil depth (Sarkar et al., 2014). It is can be explained by taking high weight coefficients of soil depth in the evaluation of land quality. In addition, the depth of the soil is very variable in the basin, which increases its impact on the assessment. Similarly, Slope degree is known to influence land quality for agricultural purpose and the assessment of land quality is important in determining soil-management practices (Paz-Kagan et al., 2016), and in recent studies, soil scientists have stated that the determination of land quality is particularly important to identify low-quality soils caused by high slopes (Vinhal-Freitas et al., 2017; Nabiollahi et al., 2018). Soil texture is another important factor used in the assessment of land quality (Aderonke and Gbadegesin, 2013), influencing the behavior of plant growth with infiltration rate, structure type and soil-water movement (Ahmed et al., 2016; Ennaji et al., 2018). In the light of past research, the effect levels of these indicators have high coefficients in the evaluation of the land quality in terms of plant cultivation.

Table 7. Pairwise comparison matrix and eigenvector of indicators in $A H P$

\begin{tabular}{|c|c|c|c|c|c|c|c|c|c|}
\hline \multicolumn{10}{|c|}{ Pairwise Comparison Matrix } \\
\hline Indicators & Depth & Slope & $\mathrm{EC}$ & Stoniness & Texture & $\mathrm{OM}$ & $\mathrm{pH}$ & $\mathrm{CaCO}_{3}$ & $\mathrm{BD}$ \\
\hline Depth & 1.00 & 2.00 & 3.00 & 3.00 & 3.00 & 3.00 & 5.00 & 5.00 & 3.00 \\
\hline Slope & 0.50 & 1.00 & 3.00 & 3.00 & 3.00 & 3.00 & 5.00 & 7.00 & 3.00 \\
\hline $\mathrm{EC}$ & 0.33 & 0.33 & 1.00 & 0.33 & 0.33 & 3.00 & 2.00 & 2.00 & 0.33 \\
\hline Stoniness & 0.33 & 0.33 & 3.00 & 1.00 & 0.33 & 3.00 & 3.00 & 3.00 & 2.00 \\
\hline Texture & 0.33 & 0.33 & 3.00 & 3.00 & 1.00 & 5.00 & 3.00 & 5.00 & 4.00 \\
\hline $\mathrm{OM}$ & 0.33 & 0.33 & 0.33 & 0.33 & 0.20 & 1.00 & 2.00 & 2.00 & 0.33 \\
\hline $\mathrm{pH}$ & 0.20 & 0.20 & 0.50 & 0.33 & 0.33 & 0.50 & 1.00 & 3.00 & 1.00 \\
\hline $\mathrm{CaCO}_{3}$ & 0.20 & 0.14 & 0.50 & 0.33 & 0.20 & 0.50 & 0.33 & 1.00 & 0.33 \\
\hline $\mathrm{BD}$ & 0.33 & 0.33 & 3.00 & 0.50 & 0.25 & 3.00 & 1.00 & 3.00 & 1.00 \\
\hline Total & 1.00 & 2.00 & 3.00 & 3.00 & 3.00 & 3.00 & 5.00 & 5.00 & 3.00 \\
\hline \multicolumn{10}{|c|}{ Normalized Pairwise Comparison Matrix } \\
\hline Indicators & Depth & Slope & $\mathrm{EC}$ & Stoniness & Texture & $\mathrm{OM}$ & $\mathrm{pH}$ & $\mathrm{CaCO}_{3}$ & $\mathrm{BD}$ \\
\hline Depth & 0.28 & 0.40 & 0.17 & 0.25 & 0.35 & 0.14 & 0.22 & 0.16 & 0.20 \\
\hline Slope & 0.14 & 0.20 & 0.17 & 0.25 & 0.35 & 0.14 & 0.22 & 0.23 & 0.20 \\
\hline $\mathrm{EC}$ & 0.09 & 0.07 & 0.06 & 0.03 & 0.04 & 0.14 & 0.09 & 0.06 & 0.02 \\
\hline Stoniness & 0.09 & 0.07 & 0.17 & 0.08 & 0.04 & 0.14 & 0.13 & 0.10 & 0.13 \\
\hline Texture & 0.09 & 0.07 & 0.17 & 0.25 & 0.12 & 0.23 & 0.13 & 0.16 & 0.27 \\
\hline $\mathrm{OM}$ & 0.09 & 0.07 & 0.02 & 0.03 & 0.02 & 0.05 & 0.09 & 0.06 & 0.02 \\
\hline $\mathrm{pH}$ & 0.06 & 0.04 & 0.03 & 0.03 & 0.04 & 0.02 & 0.04 & 0.10 & 0.07 \\
\hline $\mathrm{CaCO}_{3}$ & 0.06 & 0.03 & 0.03 & 0.03 & 0.02 & 0.02 & 0.01 & 0.03 & 0.02 \\
\hline $\mathrm{BD}$ & 0.09 & 0.07 & 0.17 & 0.04 & 0.03 & 0.14 & 0.04 & 0.10 & 0.07 \\
\hline \multicolumn{10}{|c|}{ Eigenvector } \\
\hline Indicators & \multicolumn{3}{|c|}{ Normalized Sum of Rows } & \multicolumn{4}{|c|}{ Normalized Average Rows } & \multicolumn{2}{|c|}{ Eigenvector } \\
\hline Depth & \multicolumn{3}{|c|}{2.17} & \multicolumn{4}{|c|}{$2.17 / 9$} & \multicolumn{2}{|c|}{0.242} \\
\hline Slope & \multicolumn{3}{|c|}{1.90} & \multicolumn{4}{|c|}{$1.90 / 9$} & \multicolumn{2}{|c|}{0.211} \\
\hline $\mathrm{EC}$ & \multicolumn{3}{|c|}{0.60} & \multicolumn{4}{|c|}{$0.60 / 9$} & \multicolumn{2}{|c|}{0.066} \\
\hline Stoniness & \multicolumn{3}{|c|}{0.96} & \multicolumn{4}{|c|}{$0.96 / 9$} & \multicolumn{2}{|c|}{0.106} \\
\hline Texture & \multicolumn{3}{|c|}{1.49} & \multicolumn{4}{|c|}{$1.49 / 9$} & \multicolumn{2}{|c|}{0.166} \\
\hline $\mathrm{OM}$ & \multicolumn{3}{|c|}{0.45} & \multicolumn{4}{|c|}{$0.45 / 9$} & \multicolumn{2}{|c|}{0.050} \\
\hline $\mathrm{pH}$ & \multicolumn{3}{|c|}{0.42} & \multicolumn{4}{|c|}{$0.42 / / 9$} & \multicolumn{2}{|c|}{0.047} \\
\hline $\mathrm{CaCO}_{3}$ & 0. & & & & $0.26 / 9$ & & & & \\
\hline $\mathrm{BD}$ & 0. & & & & $0.75 / 9$ & & & & \\
\hline & & $\max =$ & $\mathrm{CI}=$ & 31; CI & 0.090 & & & & \\
\hline
\end{tabular}


On the other hand, stoniness (10.6\%), bulk density (8.3\%), EC and organic matter $(5 \%)$ had moderate level of weight values. This is also a finding of the fact that the rehabilitated land conditions and the physical properties that can be improved by organic matter increasing applications can positively change the land quality index class. Thus, it has been stated that the mechanization is facilitated by the removal of the stoniness problem and increased values of crop emergence and yield in the agricultural lands were indicated (Miller and Guthrie, 1984; Sauer et al., 2010). Similarly, the positive effects of organic matter on water retention, soil compaction, aeration and biological activity reduce the restrictive effect of bulk density and improve land quality (Kurzatkowski, 2004; Guo et al., 2015). In addition, salinity problems were not determined according to EC values. However, intensive fertilizer and irrigation practices based on agricultural activities in the study area, the evaluation of salinity potential as potential risk is required (Miransari and Smith, 2007). This was reflected in the indicator's weight values and the effect of reducing the quality classes was modeled in case of a dramatic increase in EC values. With the application of $\mathrm{AHP}, \mathrm{pH}(4.7 \%)$ and $\mathrm{CaCO}_{3}$ (2.9\%) indicators established a function with low weight scores. Both factors indicate changes in the calcareous- high calcareous and slightly alkaline classes in the value ranges specific to the terrestrial climatic conditions of Central Anatolia. Although these indicators have high impacts on product-based land assessment studies (Andrews et al., 2004), due to the characteristic features in the determination of land quality at the regional scale, it has functioned at low impact levels. Thus, $\mathrm{pH}$ directly or indirectly affects many physical, chemical and biological events occurring in the soil (Baridón and Casas, 2014), it is known that phosphorus and trace elements decrease their movement ability in the soil at high $\mathrm{pH}$ values and plant uptake of toxic elements increases in acid reaction soils (Leonard et al., 1976). Similarly, it is stated that $\mathrm{CaCO}_{3}$ content is a factor that should be prevented especially in the applications such as phosphorus fertilization (Erdal et al., 2000). Therefore, it is required to functionalize $\mathrm{pH}$ and $\mathrm{CaCO}_{3}$ indicators in $\mathrm{LQI}$ for being taken into consideration in managerial planning. The LQI map generated for the Güvenç basin is presented in Fig. 2 and the LQI classes and their spatial distributions of each mapping unit are presented in Table 8.

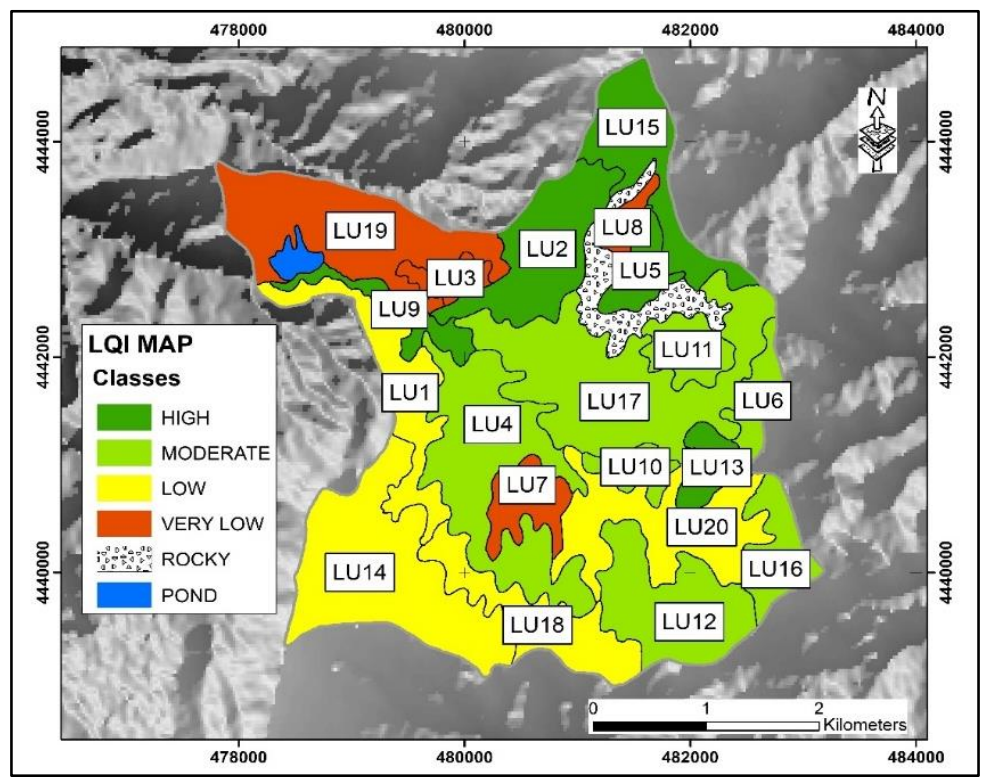

Figure 2. The map of LQI classes and distributions 
Table 8. Class sizes determined by LQI result (except pond and rocky)

\begin{tabular}{c|c|c|c|c|c|c|c}
\hline Land Units & LQI & Classes & Area (ha) & Land Units & LQI & Classes & Area (ha) \\
\hline LU1 & 2.061 & III & 82.94 & LU11 & 2.671 & II & 40.14 \\
LU2 & 2.856 & I & 108.82 & LU12 & 2.726 & II & 114.74 \\
LU3 & 2.055 & IV & 21.63 & LU13 & 3.07 & I & 28.19 \\
LU4 & 2.781 & II & 177.05 & LU14 & 2.183 & III & 197.98 \\
LU5 & 3.205 & I & 29.43 & LU15 & 3.18 & I & 98.33 \\
LU6 & 2.828 & II & 33.51 & LU16 & 2.828 & II & 49.07 \\
LU7 & 1.874 & IV & 40.97 & LU17 & 2.596 & II & 220.91 \\
LU8 & 1.949 & IV & 19.08 & LU18 & 2.061 & III & 84.32 \\
LU9 & 3.433 & I & 37.36 & LU19 & 1.843 & IV & 162.70 \\
LU10 & 2.702 & II & 24.11 & LU20 & 2.163 & III & 122.96 \\
\hline
\end{tabular}

As a result of the study, the lands indicating distribution in all conformity classes were determined in Güvenç basin. According to the generated LQI map, 302.13 ha area $(17.14 \%)$ was classified as Quality High in the study area. Although these areas have $0-1 \%$ stoniness and heavy structure together or separate effects, they are the most suitable agricultural areas within the basin. The 659.52 ha $(37.41 \%)$ of the total study area was defined as 'Moderate'. These areas have soil depths of 50-100 cm and have lands found in different slope groups (1-6). However, heavy structure factor (Heavy Clay), high bulk density for clay structure, low organic matter content and stoniness problem varying between $2-15 \%$ reduce the LQI value. As a result of LQI assessment, 732.57 ha (41.55\%) land was classified as low-very low due to soil depth of $0-50 \mathrm{~cm}$ and very steep slope $(>12 \%)$ in the study area. It was determined in the ground control that these areas were mostly used for pasture. Although this situation increased the organic matter content of soils, it did not have a class increasing effect on the final index value. In this study, it was determined that the effect of $\mathrm{pH}, \mathrm{EC}, \mathrm{CaCO}_{3}$ and organic matter indicators on quality final index values of the regional land did not create significant differences and this situation was caused by the fact that the indicators had similar values both in the fields and in themselves. The most important soil problems seen in the basin are soil depth, slope and stoniness. However, although some lands have a flat slope, high organic material content and soil depth of $25-50 \mathrm{~cm}, 5-15 \%$ stoniness problem, heavy texture and high bulk density required these areas to be classified as Low Quality. Similarly, areas with $0-2 \%$ stoniness, high organic matter and $5-15 \% \mathrm{CaCO}_{3}$ content but soil depth of $0-25 \mathrm{~cm}$ and slope of $6-12 \%$ were also included in the very low-quality class. However, it is foreseen that if the necessary conservation measures are taken (ground leveling planning, deep tillage and cracking, addition of organic matter, stone collection), the low-quality regional lands can be classified as moderate or high quality.

\section{Validation of the LQI}

The final index values of the quality classes determined as a result of the LQI evaluation were compared with NDVI ratios derived from Sentinel-2A satellite image in 2018-May using linear regression analysis. The evaluation of the data, $r^{2}=0.74 \%$ relationship was determined (Fig. 3).

The validation values obtained showed that the use of AHP-LCT in sub-factor weighting of selected criteria for LQI gave reliable results. At the same time, it was concluded that NDVI values can be used to test the index developed in cases where biomass data of vegetation are limited in local based studies. Similarly, a significant 
correlation was observed between the NDVI values of plants for the month of May and biomass $\left(r^{2}=0.69\right)$, using the SPOT 2 satellite images (Usul, 2010). Further, a strong correlation was reported between NDVI and biomass density (Salazar et al., 2007; Olimb et al., 2018; Li et al., 2019), and NDVI provided a more accurate estimation of biomass than the other vegetation index for the purpose of assessing land cover and soil quality by remote sensing technique (de Paul Obade and Lal, 2013; Lambert et al., 2018).

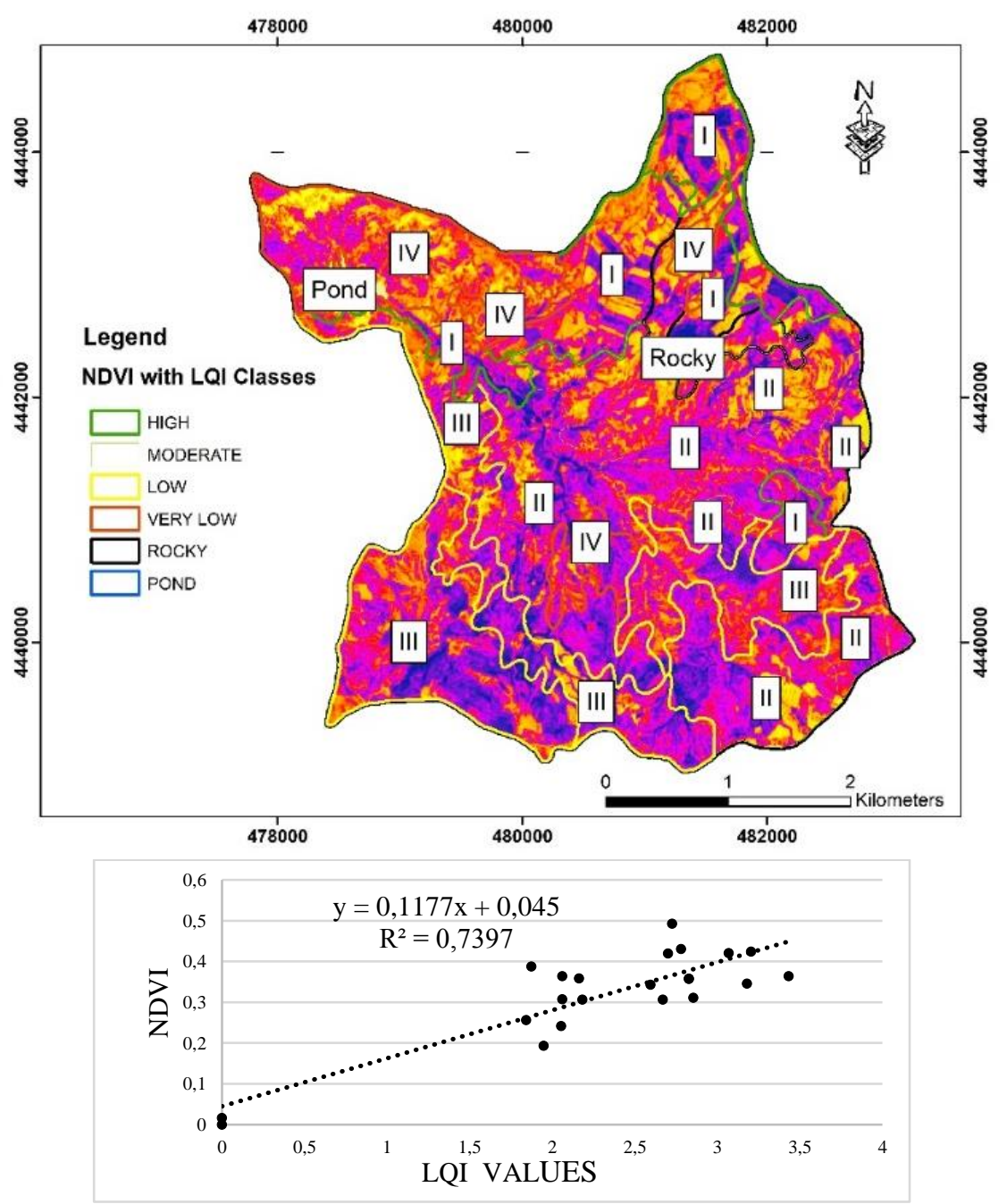

Figure 3. Distribution of LQI classes on NDVI map from Sentienel 2A and regression graph

\section{Conclusion}

In order to determine the quality index of agricultural land, which is compatible for semi-arid climate and integrated with GIS a practical LQI has been developed and found successful in Central Anatolia region due to showing a high relationship with canopy reflectance values. The most remarkable finding of the study is that the parameters selected for the LQI is the necessity to represent the study area, their topography, and the change in soil properties. In this way, region-specific evaluations can be made, and more reliable results are obtained. Thus, nine parameters used in the determination of land quality classes for Güvenç Basin reflect both the regional pedology and the effect of 
climate characteristics. Another important point here is the weighting of the effect level of the selected parameters on each other and on the land quality. The AHP method used for pairwise comparison and weighting of parameters in the study presented a reliable index approach in the determination of land quality for agricultural purposes. While the relationship between each factor and AHP method is revealed, it is consistent to make common decision weights where the literature knowledge and expert opinion overlap (Expert System). Thus, the study showed similarity with the previous research findings that AHP has high capacity for integration of heterogeneous data. The obtained all findings showed that the development and use of region-specific index in the determination of the quality of agricultural land will enable the production of more accurate and reliable policies. In this way, climate, physiography and soil characteristics of different geographies can be evaluated within itself. Otherwise, evaluating our own lands with parametric approaches which are used in many studies but developed in different region ecologies causes wrong inferences. For instance, public institutions in Turkey for producing agricultural policy uses the Storie Index for land evaluation and classification. However, this approach scores the characteristics of the terrain indicated in the scoring of parameters to the same extent for different geographies. This reduced sensitivity in the assessment of land of different geography, such ecology particularly Turkey. At the same time, the indicator ratios specified in many parametric models are multiplied by each other and the effect level of each indicator is considered equal in terms of agriculture. In this case, even if a very important parameter such as effective soil depth in terms of agricultural land quality gets low score, high value of other parameters decreases the level effect of depth and improves the class of agricultural land quality. The most important advantage of regional-based index approaches is that, in addition to subcategorizing the selected indicators at a regional scale, they weight the relevant indicators according to the regional characteristics. Thus, all factors can be evaluated according to the importance level of the specific region. However, since the different indicators (e.g. macro-micronutrients, heavy metals, biological factors) can be easily adapted to the index, it can be suggested that they can be reconstructed in areas indicating different soil properties. With all these evaluations and contributions, it will be ensured that the index fully represents the ecology of the region in which it is developed. The capabilities of satellite images of the basin were also utilized in the study. Our results have demonstrated the potential use of NDVI derived from high-resolution, multitemporal Sentinel-2A images for the comparison of biomass density with land quality scores in the basin. Similar studies have suggested that if there is limited data on vegetation, a different option of validation may be used. Moreover, the usability of vegetation indices for monitoring and estimation of land quality was evaluated with a different perspective and a window was opened for future research. In this way, changes in land quality determined by using parameters which were representing agricultural areas can be monitored by using vegetation indices in the following years compared with the past findings, and the cause of radical changes in biomass reflections could be determined by field studies. As a matter of fact, sustainable agricultural techniques suggest applications based on sustainability of land quality and productivity for agriculture areas in today and future. Consequently, land quality map for study area generated using AHP, GIS and LCT, can enhance the planning alternatives within an area with meaningful strategy in terms of location. Therefore, the present model will provide logical guidance for new land allocation of agricultural usage for decision makers. 


\section{REFERENCES}

[1] Aderonke, D. O., Gbadegesin, G. A. (2013): Spatial variability in soil properties of a continuously cultivated land. - African Journal of Agricultural Research 8(5): 475-483.

[2] Ahmed, G. B., Shariff, A. R. M., Balasundram, S. K., bin Abdullah, A. F. (2016): Agriculture land suitability analysis evaluation based multi criteria and GIS approach. - In: IOP Conference Series. Earth and Environmental Science 37(1): 12-44.

[3] Akıncı, H., Özalp, A. Y., Turgut, B. (2013): Agricultural land use suitability analysis using GIS and AHP technique. - Computers and Electronics in Agriculture 97(2013): 71-82.

[4] Aldababseh, A., Temimi, M., Maghelal, P., Branch, O., Wulfmeyer, V. (2018): Multicriteria evaluation of irrigated agriculture suitability to achieve food security in an arid environment. - Sustainability 10(3): 803.

[5] Al-Doski, J., Mansor, S. B., Shafri, H. Z. M. (2013): NDVI differencing and postclassification to detect vegetation changes in Halabja city, Iraq. - IOSR Journal of Applied Geology and Geophysics 1(2): 01-10.

[6] An, S. (2018): Research on Dynamic Change and Relationship Between Land Use/Cover and Evapotranspiration in Beijing-Tianjin-Hebei Region. - Hebei University of Science and Technology Publishing, China.

[7] Andrews, S. S., Karlen, D. L., Cambardella, C. A. (2004): The soil management assessment framework: A quantitative soil quality evaluation method. - Science Society of America 68(6): 1945-1962.

[8] Anonymous (2017): Turkish state meteorological service. - https://mgm.gov.tr/eng/ forecast-cities.aspx.

[9] Arshad, M. A., Martin, S. (2002): Identifying critical limits for soil quality indicators in agro-ecosystems. - Ecosystems \& Environment 88(2002): 153-160.

[10] Askari, M. S., Holden, N. M. (2014): Indices for quantative evaluation of soil quality under grassland management. - Geoderma 230(2014): 131-142.

[11] Baridón, J. E., Casas, R. R. (2014): Quality indicators in subtropical soils of formosa, Argentina: changes for agriculturization process. - International Soil and Water Conservation Research 2(4): 13-24.

[12] Blake, G. R., Hartge, K. H. (1986): Bulk Density. - In: Klute, A. (ed.) Methods of Soil Analysis, Physical and Mineralogical Methods. Soil Science Society of America, Madison, pp. 363-376.

[13] Bouyoucos, G. J. (1951): A recalibration of the hydrometer method for making mechanical analysis of soils. - Agronomy Journal 43(9): 434-438.

[14] Bydekerke, L., Van Ranst, E., Vanmechelen, L., Groenemans, R. (1998): Land suitability assessment for Cherimoya in Southern Ecuador using expert knowledge and GIS. Agriculture, Ecosystems \& Environment 69(2): 89-98.

[15] Campbell, J. B., Wynne, R. H. (2011): Introduction to Remote Sensing. - Guilford Press, New York.

[16] Ceballos, S. A., López, B. J. (2003): Delineation of suitable areas for crops using a multicriteria evaluation approach and land use/cover mapping: A case study in Central Mexico. - Agricultural Systems 77(2003): 117-136.

[17] De la Rosa, D., Van Diepen, C. A. (2009): Qualitative and Quantitative Land Evaluations. - In: Verheye, W. H. (ed.) Encyclopedia of Land Use, Land Cover and Soil Sciences Volume II. Eolss Publishers, Oxford, United Kingdom.

[18] de Paul Obade, V., Lal, R. (2013): Assessing land cover and soil quality by remote sensing and geographical information systems (GIS). - Catena 104(2013): 77-92.

[19] DeFries, R., Hansen, M., Townshend, J. (1995): Global discrimination of land cover types from metrics derived from AVHRR pathfinder data. - Remote Sensing of Environment 54(3): 209-222.

[20] Dengiz, O., Başkan, O. (2005): Basic properties and classification of Güvenç Basin soil, Ankara. - Selcuk J Agr Food Sci. 19(37): 27-36. 
[21] Dengiz, O., Sarığlu, F. E. (2013): Parametric approach with linear combination technique in land evaluation studies. - Journal of Agricultural Sciences 19(2): 101-112.

[22] Dengiz, O., Şişman, A., Gülser, C., Şişman, Y. (2014): Alternative approach for land quality classification used for land consolidation. - Soil and Water Journal 3(1): 59-69.

[23] Doran, J. W., Parkin, T. B. (1996): Quantitative Indicators of Soil Quality: a Minimum Data Set. - In: Doran, J. W., Jones, A. J. (eds.) Methods for Assessing Soil Quality. Soil Science Society of America Special Publication, Madison, pp. 25-37.

[24] Eastman, J. R., Jiang, H. (1996): Fuzzy Measures in Multi-Criteria Evaluation. - United States Department of Agriculture Forest Service General Technical Report RM, 527-534.

[25] Ennaji, W., Barakat, A., El Baghdadi, M., Oumenskou, H., Aadraoui, M., Karroum, L. A., Hilali, A. (2018): GIS-based multi-criteria land suitability analysis for sustainable agriculture in the northeast area of Tadla plain (Morocco). - Journal of Earth System Science 127(6): 79 .

[26] Erdal, İ., Bozkurt, M. A., Çimrin, K. M., Karaca, S., Sağlam, M. (2000): Effects of humic acid and phosphorus applications on growth and phosphorus uptake of corn plant (Zea mays L.) grown in a calcareous soil. - Turkish Journal of Agriculture and Forestry 24(2000): 663-668.

[27] ERDAS (2009): User's guide. - http://www.erdas.com.

[28] ESRI (2010): User's guide. - http://www.esri.com.

[29] FAO (1977): A Framework for Land Evaluation. - International Institute for Land Reclamation and Improvement Published No.22, Wageningen.

[30] Garrigues, S., Allard, D., Baret, F. (2007): Using first-and second-order variograms for characterizing landscape spatial structures from remote sensing imagery. - IEEE Transactions on Geoscience and Remote Sensing 45(6): 1823-1834.

[31] Guo, L. J., Zhang, Z. S., Wang, D. D., Li, C. F., Cao, C. G. (2015): Effects of short-term conservation management practices on soil organic carbon fractions and microbial community composition under a rice-wheat rotation system. - Biology and Fertility of Soils 51(1): 65-75.

[32] Hazelton, P., Murphy, B. (2007): Interpreting Soil Test Results, What Do All the Numbers Mean. - Commonwealth Scientific and Industrial Research Organization Publishing, Australia.

[33] Huddleston, J. H., Pease, J. R., Forrest, W. G., Hickerson, H. J., Langridge, R. W. (1987): Use of agricultural land evaluation and site assessment in Linn County, Oregon, USA. Environmental Management 11(3): 389-405.

[34] Imaz, M. J., Virto, I., Bescansa, P., Enrique, A., Fernandez, A. O., Karlen, D. L. (2010): Soil quality indicator response to tillage and residue management on semi-arid Mediterranean cropland. - Soil and Tillage Research 107(1): 17-25.

[35] Iojă, C. I., Niţă, M. R., Vânău, G. O., Onose, D. A., Gavrilidis, A. A. (2014): Using multicriteria analysis for the identification of spatial land-use conflicts in the Bucharest Metropolitan area. - Ecological Indicators 42(2014): 112-121.

[36] Jenks, G. F. (1967): The data model concept in statistical mapping. - International Yearbook of Cartography 7(1967): 186-190.

[37] Joshua, J. K., Anyanwu, N. C., Ahmed, A. J. (2013): Land suitability analysis for agricultural planning using GIS and multi criteria decision analysis approach in Greater Karu Urban Area, Nasarawa State, Nigeria. - Afr J Agric Sci Technol 1(1): 14-23.

[38] Karlen, D. L., Gardner, J. C., Rosek, M. J. (1998): A soil quality framework for evaluating the impact of CRP. - Journal of Production Agriculture 11(1): 56-60.

[39] Karlen, D. L., Cambardella, C. A., Kovar, J. L., Colvin, T. S. (2013): Soil quality response to long-term tillage and crop rotation practices. - Soil and Tillage Research 133(2013): 5464.

[40] Kumar, T., Jhariya, D. C. (2015): Land quality index assessment for agricultural purpose using multi-criteria decision analysis (MCDA). - Geocarto International 30(7): 822-841. 
[41] Kurzatkowski, D., Martius, C., Höfer, H., Garcia, M., Förster, B., Beck, L., Vlek, P. (2004): Litter decomposition, microbial biomass and activity of soil organisms in three agroforestry sites in Central Amazonia. - Nutrient Cycling in Agroecosystems 69(3): 257-267.

[42] Lambert, M. J., Traoré, P. C. S., Blaes, X., Baret, P., Defourny, P. (2018): Estimating smallholder crops production at village level from Sentinel-2 time series in Mali's cotton belt. - Remote Sensing of Environment 216(2018): 647-657.

[43] Leonard, W. H., Stamp, D. L., Martin, J. H. (1976): Principles of Field Crop Production. Macmillan Publishing Company, New York.

[44] Li, C., Li, H., Li, J., Lei, Y., Li, C., Manevski, K., Shen, Y. (2019): Using NDVI percentiles to monitor real-time crop growth. - Computers and Electronics in Agriculture 162(2019): 357-363.

[45] Malczewski, J. (2006): Ordered weighted averaging with fuzzy quantifiers: GIS-based multicriteria evaluation for land-use suitability analysis. - International Journal of Applied Earth Observation and Geoinformation 8(4): 270-277.

[46] McVay, K., Radcliffe, D., Hargrove, W. L. (1989): Winter legume effects on soil properties and nitrogen fertilizer requirements. - Soil Science Society of America Journal 53(6): 1856-1862.

[47] Mezera, J., Lukas, V., Elbl, J. (2017): Evaluation of crop yield spatial variability in relation to variable rate application of fertilizers. - MendelNet 24(1).

[48] Miller, F., Guthrie, R. L. (1984): Classification and Distribution of Soils Containing Rock Fragments in the United States. Erosion and Productivity of Soils Containing Rock Fragments. - Soil Science Society of America Publishing, Madison, pp. 1-6.

[49] Miransari, M., Smith, D. L. (2007): Overcoming the stressful effects of salinity and acidity on soybean nodulation and yields using signal molecule genistein under field conditions. Journal of Plant Nutrition 30(12): 1967-1992.

[50] Mokarram, M., Mirsoleimani, A. (2018): Using Fuzzy-AHP and order weight average (OWA) methods for land suitability determination for citrus cultivation in ArcGIS (Case study: Fars province, Iran). - Physica A: Statistical Mechanics and its Applications 508(2018): 506-518.

[51] Mustafa, S. M. T., Vanuytrecht, E., Huysmans, M. (2017): Combined deficit irrigation and soil fertility management on different soil textures to improve wheat yield in drought-prone Bangladesh. - Agricultural Water Management 191(2017): 124-137.

[52] Nabiollahi, K., Golmohamadi, F., Taghizadeh-Mehrjardi, R., Kerry, R., Davari, M. (2018): Assessing the effects of slope gradient and land use change on soil quality degradation through digital mapping of soil quality indices and soil loss rate. - Geoderma 318(2018): 16-28.

[53] Nelson, D. W., Sommers, L. (1982): Total Carbon, Organic Carbon, and Organic Matter. - In: Page, A. L. (ed.) Methods of Soil Analysis, Part 2: Chemical and Microbiological Properties. American Society of Agronomy, Inc., and Soil Science Society of America, Inc., Madison, pp. 539-579.

[54] Olimb, S. K., Dixon, A. P., Dolfi, E., Engstrom, R., Anderson, K. (2018): Prairie or planted? Using time-series NDVI to determine grassland characteristics in Montana. GeoJournal 83(4): 819-834.

[55] Özkan, B., Dengiz, O., Demirăg, T. İ. (2019): Site suitability assessment and mapping for rice cultivation using multi-criteria decision analysis based on fuzzy-AHP and TOPSIS approaches under semihumid ecological condition in delta plain. - Paddy and Water Environment 2019: 1-12.

[56] Pagliai, M., Vignozzi, N., Pellegrini, S. (2004): Soil structure and the effect of management practices. - Soil and Tillage Research 79(2): 131-143.

[57] Pandžić, M., Mihajlović, D., Pandžić, J., Pfeifer, N. (2016): Assessment of the geometric quality of Sentinel-2 data. - International Archives of the Photogrammetry, Remote Sensing \& Spatial Information Sciences 41: 489-494. 
[58] Pasqualotto, N., Delegido, J., Van Wittenberghe, S., Rinaldi, M., Moreno, J. (2019): Multicrop green LAI estimation with a new simple Sentinel-2 LAI index (SeLI). - Sensors 19(4): 904.

[59] Patrono, A. (1998): Multi-Criteria Analysis and Geographic Information Systems: Analysis of Natural Areas and Ecological Distributions. Multicriteria Analysis for Land-Use Management. - In: Beinat, E. (ed.) Environment and Management. Kluwer Academic Publishers, The Netherlands, pp. 271-292.

[60] Paz-Kagan, T., Ohana-Levi, N., Herrmann, I., Zaady, E., Henkin, Z., Karnieli, A. (2016): Grazing intensity effects on soil quality: A spatial analysis of a Mediterranean grassland. Catena 146(2016): 100-110.

[61] Rahmanipour, F., Marzaioli, R., Bahrami, H. A., Fereidouni, Z., Bandarabadi, S. R. (2014): Assessment of soil quality indices in agricultural lands of Qazvin Province, Iran. Ecological Indicators 40(2014): 19-26.

[62] Riley, H., Pommeresche, R., Eltun, R., Hansen, S., Korsaeth, A. (2008): Soil structure, organic matter and earthworm activity in a comparison of cropping systems with contrasting tillage, rotations, fertilizer levels and manure use agriculture. - Ecosystems \& Environment 124(3-4): 275-284.

[63] Romano, G., Dal Sasso, P., Trisorio Liuzzi, G., Gentile, F. (2015): Multi-criteria decision analysis for land suitability mapping in a rural area of Southern Italy. - Land Use Policy 48(2015): 131-143.

[64] Saaty, T. L. (1980): The Analytical Hierarchy Process, Planning, Priority. - Resource Allocation: RWS Publications, USA.

[65] Saaty, T. L. (2008): Decision making with the analytic hierarchy process. - International Journal of Services Sciences 1(1): 83-98.

[66] Salazar, L., Kogan, F., Roytman, L. (2007): Use of remote sensing data for estimation of winter wheat yield in the United States. - International Journal of Remote Sensing 28(17): 3795-3811.

[67] Sarkar, A., Ghosh, A., Banik, P. (2014): Multi-criteria land evaluation for suitability analysis of wheat: A case study of a watershed in eastern plateau region, India. - GeoSpatial Information Science 17(2): 119-128.

[68] Sauer, T., Havlík, P., Schneider, U. A., Schmid, E., Kindermann, G., Obersteiner, M. (2010): Agriculture and Resource availability in a changing world: The role of irrigation. - Water Resources Research 46(6): 1-12.

[69] Shepherd, T. G. (2009): Visual Soil Assessment: Field Guide for Pastoral Grazing and Cropping on Flat to Rolling Country. - Horizons Regional Council, Palmerston North, New Zealand.

[70] Singh, J., Devi, U., Hazra, J., Kalyanaraman, S. (2018): Crop-identification using Sentinel1 and Sentinel-2 data for Indian region. - In: IGARSS 2018, IEEE International Geoscience and Remote Sensing Symposium, pp. 5312-5314.

[71] Soil Science Division Staff. (2017): Soil Survey Manual. - USDA-NRCS. U.S. Gov. Print. Off, Washington, DC., Handbook No 18.

[72] Soil Survey Staff. (1999): Soil Taxonomy: A Basic System of Soil Classification for Making and Interpreting Soil Surveys. - US Government Printing Office.

[73] Soil Survey Staff. (2011): Soil Survey Laboratory Methods Manual: Soil Survey Investigations Report. - Lincoln, NE.

[74] Song, R., Cheng, T., Yao, X., Tian, Y., Zhu, Y., Cao, W. (2016): Evaluation of Landsat 8 time series image stacks for predicting yield and yield components of winter wheat. - In: IGARSS 2016, IEEE International Geoscience and Remote Sensing Symposium, pp. 63006303.

[75] Store, R., Kangas, J. (2001): Integrating spatial multi-criteria evaluation and expert knowledge for GIS-based habitat suitability modelling. - Landscape and Urban Planning 55(2): 79-93. 
[76] Şeker, C., Iş1ldar, A. (2000): Effects of wheel traffic porosity and compaction of soil profile. - Turkish Journal of Agriculture and Forestry 24(2000): 71-77.

[77] Tucker, C. J. (1979): Red and photographic infrared linear combinations for monitoring vegetation. - Remote Sensing of Environment 8(2): 127-150.

[78] Turan, İ. D., Dengiz, O. (2015): Erosion risk prediction using multi-criteria assessment in Ankara Güvenç Basin. - Journal of Agricultural Sciences 23(3): 285-297.

[79] Turgut, B., Aksakal, E. L., Öztaş, T., Babagil, G. E. (2008): Defining partial effect coefficients of soil properties affecting on soil penetration resistance using multiple regression analysis. - Atatürk University Journal of The Agricultural Faculty 39(1): 115121.

[80] Tyagi, P., Bhosle, U. (2010): Image based atmospheric correction of remotely sensed images. - In: Computer Applications and Industrial Electronics (ICCAIE) 2010 International Conference, pp. 63-68.

[81] Usul, M. (2010): Determination of Effects of Land Quality Parameters on Wheat Yield by using Remote Sensing and Geographic Information Systems, Case Study; Altinova State Farm. - Ankara University, PhD Thesis (published).

[82] Van Wambeke, A. R. (2000): The Newhall Simulation Model for Estimating Soil Moisture \& Temperature Regimes Preliminary Assumptions of the Newhall Model. - Geogr. Rev. $1-9$.

[83] Vinhal-Freitas, I. C., Corrêa, G. F., Wendling, B., Bobul'ská, L., Ferreira, A. S. (2017): Soil textural class plays a major role in evaluating the effects of land use on soil quality indicators. - Ecological Indicators 74(2017): 182-190.

[84] Xue, R., Wang, C., Liu, M., Zhang, D., Li, K., Li, N. (2019): A new method for soil health assessment based on analytic hierarchy process and meta-analysis. - Science of The Total Environment 650(2019): 2771-2777.

[85] Yalew, S. G., van Griensven, A., Mul, M. L., van der Zaag, P. (2016): Land suitability analysis for agriculture in the Abbay basin using remote sensing, GIS and AHP techniques. - Modeling Earth Systems and Environment 2(101).

[86] Yang, F., Zeng, G., Du, C., Tang, L., Zhou, J., Li, Z. (2008): Spatial analyzing system for urban land-use management based on GIS and multi-criteria assessment modeling. Progress in Natural Science 18(2008): 1279-1284.

[87] Zhan, A., Zou, C., Ye, Y., Liu, Z., Cui, Z., Chen, X. (2016): Estimating on-farm wheat yield response to potassium and potassium uptake requirement in China. - Field Crops Research 191(2016): 13-19.

[88] Zhang, B., Zhang, Y., Chen, D., White, R. E., Li, Y. (2004): A quantitative evaluation system of soil productivity for intensive agriculture in China. - Geoderma 123(3-4): 319331.

[89] Zhang, J., Su, Y., Wu, J., Liang, H. (2015): GIS based land suitability assessment for tobacco production using ahp and fuzzy set in Shandong Province of China. - Computers and Electronics in Agriculture 114(2015): 202-211. 